https://dx.doi.org/10.4314/ijs.v20i2.5

Ife Journal of Science vol. 20, no. 2 (2018)

\title{
SCREENING FOR CYTOTOXIC AND GENOTOXIC EFFECTS ON SELECTED PLANTS FROM SITES ROUTINELY MAINTAINED BY HERBICIDE APPLICATION IN THE ILE-IFE MUNICIPALITY
}

\author{
Bulu Y. I. ${ }^{1 *}$, Faluyi J. O. ${ }^{2}$ and Adewole M. B. ${ }^{3}$ \\ ${ }^{1}$ Department of Plant Science and Biotechnology, Faculty of Science, Adekunle Ajasin University, Akungba Akoko, \\ Ondo State. \\ ${ }^{2}$ Department of Botany, Faculty of Science, Obafemi Awolowo University, Ile-Ife, Nigeria; email address - \\ jfaluyi@gmail.com, Tel: 08037250857. \\ ${ }^{3}$ Institute of Ecology and Environmental Studies, Obafemi Awolowo University, Ile-Ife, Nigeria; email address - \\ mbamideleadewole@gmail.com, Tel: 08034784267 \\ *Corresponding author email address - yetunde.bulu@aaua.edu.ng, Tel: 08038567413 \\ (Received: $8^{\text {th }}$ October, 2017; Accepted: $29^{\text {th }}$ March, 2018)
}

\section{ABSTRACT}

\begin{abstract}
The use of herbicides in non-agricultural or urban amenity areas may lead to different environmental issues relating to human safety, integrity of the environment and associated collateral effects which do not arise when they are used in agriculture. This study therefore seeks to determine the genotoxicity and cytotoxicity effects on the long-surviving plants identified in Ile-Ife municipality where herbicides are used routinely for weed control. Pollen grain size distribution, fertility and cytological examination were carried out on accessions of Talinum triangulare and Paspalum conjugatum which were the dominant and long-surviving plant populations of the study sites. The pattern of pairing, segregation of chromosomes to the poles and the morphology of the meiocytes and related cells were investigated. The pollen grains of the plants studied showed regularity in size, shape and high stainability. The distribution of pollen grain sizes was unimodal in all the plants monitored. They are able to survive herbicide application without manifesting cytotoxic and genotoxic effects. The results of this study showed that plants that are long-living survived as a result of the nature of their perennating organs.
\end{abstract}

Keywords: Herbicide application, cytotoxic effect, genotoxic effect, Talinum triangulare, Paspalum conjugatum

\section{INTRODUCTION}

Heavy dependence on herbicides causes persistence of their active principles within the environment and the food chain with documented cases of mitotic abnormalities, DNA mutation, alteration of protein banding patterns in normal soil flora and fauna and increased cases of toxicity to the human. Repeated and intensive use of herbicides with the same mechanisms of action can rapidly select for shifts to tolerant, difficult-tocontrol weeds and consequently the evolution of herbicide-resistant weeds, especially in the absence of the concurrent use of herbicides with different mechanisms of action, the use of mechanical or cultural practices or both (Vencill et al., 2012).

Cytological investigations have been carried out to detect the harmful effects of agricultural chemicals on various crop plants with chromosome aberrations used as a measure of reproductive success (Njagi and Goplan, 1981; Pandey, 2008; Kumar and Jagannath, 2015).
Kumar and Jagannath (2015) reported increasing chromosomal abnormalities (sticky chromatin, chromosomal bridge, nuclear lesion, scattered chromosomes, fragmented metaphase, fragmented anaphase, multipolar chromosomes and micronuclei) with increasing concentration when butachlor herbicide was used in treating the somatic cells of Triticum aestivum. Pandey (2008) studied the effects of pesticides on the cell division and chromosomal morphology of Vicia faba $\mathrm{L}$. The results showed that the pesticides are mitodepressive in higher concentrations and mitopromotor in lower concentrations and induced a variety of chromosomal abnormalities. These findings had also been supported by the work of Haliem (1990) who monitored the effects of sencorer herbicide on the mitosis of Alium cepa roots and Topaktas and Rencuzogullari (1991) who studied the cytogenetic effects of herbicidesgasegard and igran in barley.

Apart from the effects of agricultural chemicals, the effect of radiation on the cytological behavior 
of plants had been monitored. Lower radiation levels have a positive effect on plant growth as against high levels. Faluyi and Nwokeocha (2001) monitored radiation damage in four cassava varieties exposed to nine levels of gamma radiation between 5 and 250 gray cytogenetically. Foliar defects increasing with dosage were observed on the shoots from the treated cuttings but these disappeared within two months for all the varieties. Flower buds harvested from the varietal cuttings were studied meiotically and the general features were regular bivalent pairing as $18 \mathrm{II}$ (8 ring II +10 rod II); lack of laggards and fragments at Anaphase and well-stained pollens indicating high fertility for the treatments and their controls.

In spite of these great advances made in understanding chromosomal behaviour of various plant species under varying environmental conditions, chromosome behaviour of plants in environments where herbicides are used routinely for ambience maintenance remain poor or nonexistent. This study therefore attempts to assess the genotoxicity effects of repeated use of different types of herbicides on the surviving weed plants in selected sites in Ile-Ife municipality in Osun State, Nigeria.

\section{MATERIALS AND METHODS}

Pollen grain and chromosome studies were carried out on plants collected from site treated with herbicides and those not treated with herbicides which serve as the control. The treated site and the control were $10 \mathrm{~m}$ apart. Three plant species Talinum triangulare, Paspalum conjugatum and Gomphrena celosioides were collected over a period of time. These were the dominant plant species that have survived repeated and different types of herbicide application in the sites studied. The parameters of pollen studied were size, shape and fertility (stainability was the index used to assess the fertility). The pollen grains were scored for stainability at x 40 magnification and percentage stainability calculated.
Well-formed intact and uniformly-stained pollen grains were considered viable while those that were only partially stained or not stained at all and with collapsed outlines were scored as non-viable (Olorode and Baquar, 1976). Diameters of pollen grains were measured at $x 40$ in ocular units which were then converted to micrometers. Estimate of mean pollen size was based on measurement of 100 pollen grains for each accession. Meiotic chromosome study was carried out by using flower buds that were collected between 9 am and 12 noon and stored in 1:3 acetic-alcohol. Anthers from the flower buds were harvested and pollen were shaken onto slides and stained in situ with cotton blue in lactophenol. Flower buds were prepared for chromosome studies by squash technique and stained in FLP-orcein according to Lasebikan and Olorode (1972).

Pollen mother cells were examined and good chromosomes were scored for associations. Good spreads were photographed under oil and phase contrast illumination under a microscope equipped with DCM 500 digital camera.

\section{RESULTS}

Table 1 shows the accessions used for genotoxic studies. Cytological examination carried out on accessions of Talinum triangulare and Paspalum conjugatum showed that meiosis was regular with the chromosomes showing a modal pairing of $18 \mathrm{II}$ in Talinum triangulare and $10 \mathrm{II}$ in Paspalum conjugatum. The segregation of the chromosomes was normal as shown in telophase I and telophase II in Talinum triangulare and did not have laggards and restitution nuclei (Plate 1). The data in table 1 support this observation with 100\% normal segregation at anaphase I, telophase I and II.

The pollen grains of the selected plants showed regularity in size, shape and stainability. The distribution of pollen grain size is unimodal in all the plants monitored as shown in figure 1 . 
Table 1: Description of selected plants used for cytotoxic and genotoxic study

\begin{tabular}{|c|c|c|c|c|c|c|}
\hline $\mathrm{S} / \mathrm{N}$ & Accession & & Description & $\begin{array}{l}\text { Modal } \\
\text { chromosome } \\
\text { configuration }\end{array}$ & $\begin{array}{l}\% \text { Regular } \\
\text { segregation }\end{array}$ & $\begin{array}{l}\text { Pollen } \\
\text { fertility } \\
(\%)\end{array}$ \\
\hline 1 & $\begin{array}{l}\text { OL } 04.13 .16 \\
\text { Talinum triangulare }\end{array}$ & -01 & $\begin{array}{l}\text { Plant recovering from } \\
\text { herbicide application. }\end{array}$ & $\begin{array}{l}15 \operatorname{ring} \mathrm{II}+3 \\
\operatorname{rod} \mathrm{II}\end{array}$ & 100 & 78 \\
\hline 2 & $\begin{array}{l}\text { OL } 04.13 .16 \\
\text { Paspalum conjugatum }\end{array}$ & -02 & $\begin{array}{l}\text { Leaves necrotic, young leaves } \\
\text { in flush at recovery from } \\
\text { herbicide treatment }\end{array}$ & 10 ring II & 100 & 100 \\
\hline 3 & $\begin{array}{l}\text { OL } 04.13 .16 \\
\text { Paspalum conjugatum }\end{array}$ & -03 & $\begin{array}{l}\text { Plant selected from control } \\
\text { site of full vegetation. }\end{array}$ & & - & 100 \\
\hline 4 & $\begin{array}{l}\text { OL 04.13.16-04 } \\
\text { Talinum triangulare }\end{array}$ & & As for 3 & & - & 100 \\
\hline 5 & $\begin{array}{l}\text { OL } 04.21 .16 \\
\text { Talinum triangulare }\end{array}$ & -01 & $\begin{array}{l}\text { Site still under recovery from } \\
\text { herbicide treatment }\end{array}$ & & - & 100 \\
\hline 6 & $\begin{array}{l}\text { OL } 04.21 .16-02 \\
\text { Talinum triangulare }\end{array}$ & & As for 5 & & - & 100 \\
\hline 7 & $\begin{array}{l}\text { OL 04.21.16-03 } \\
\text { Paspalum conjugatum }\end{array}$ & & $\begin{array}{l}\text { Plant luxuriant and flowering } \\
\text { in the control site. }\end{array}$ & & - & 100 \\
\hline 8 & $\begin{array}{l}\text { OL 04.21.16-04 } \\
\text { Paspalum conjugatum }\end{array}$ & & As for 3 & & - & 100 \\
\hline 9 & $\begin{array}{l}\text { EW 04.22.16-01 } \\
\text { Gomphrena celosioides }\end{array}$ & & $\begin{array}{l}\text { Plant s elected from control } \\
\text { site of full vegetation. }\end{array}$ & & - & 90 \\
\hline 10 & $\begin{array}{l}\text { EW 04.22.16-02 } \\
\text { Gomphrena celosioides }\end{array}$ & & $\begin{array}{l}\text { Site recovering from } \\
\text { herbicide treatment. }\end{array}$ & & - & 94 \\
\hline
\end{tabular}




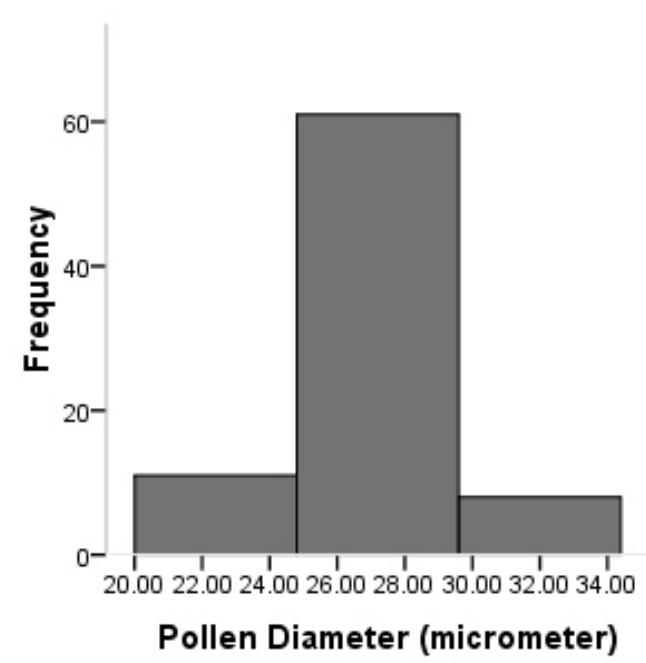

Control

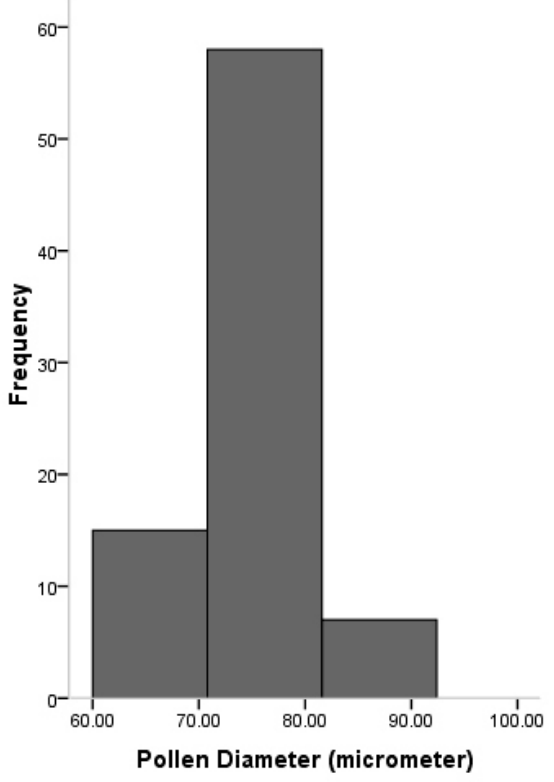

Control

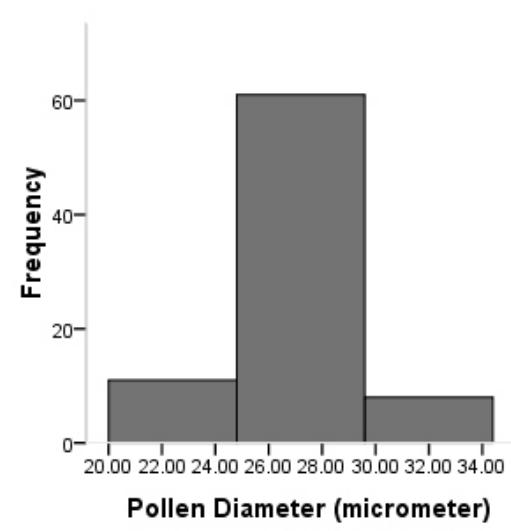

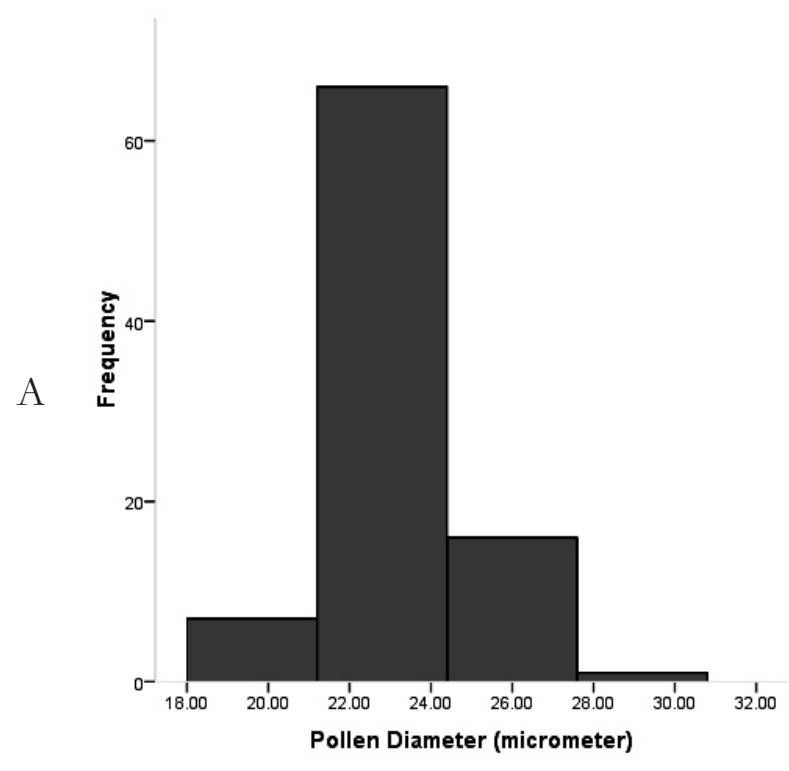

Treated

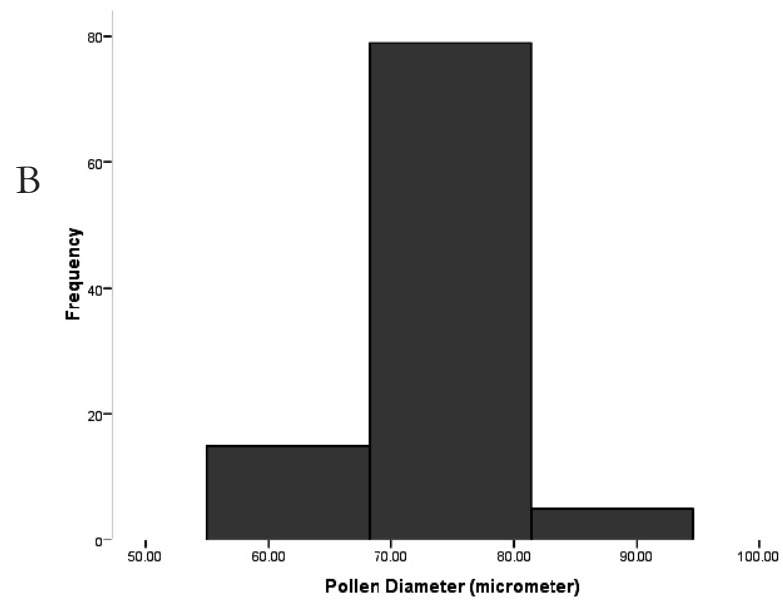

Treated

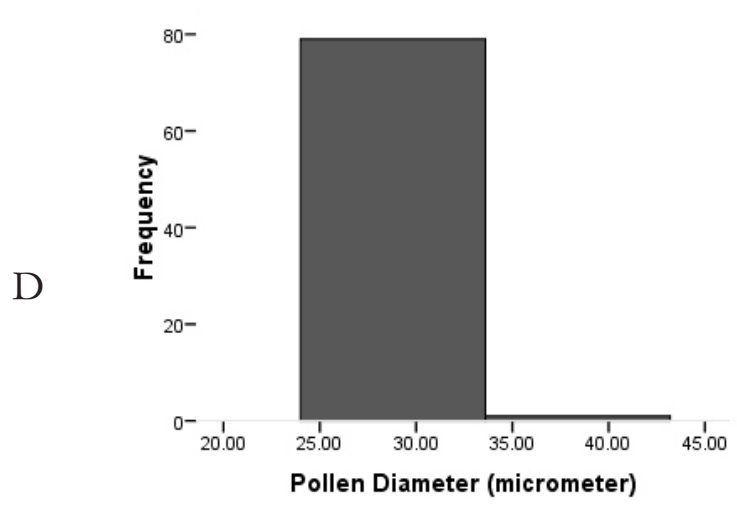

Treated

Figure 1: Histogram of pollen size distribution in control and treated varieties.

A Gomphrena celosioides B Talinum triangulare C Paspalum conjugatum 

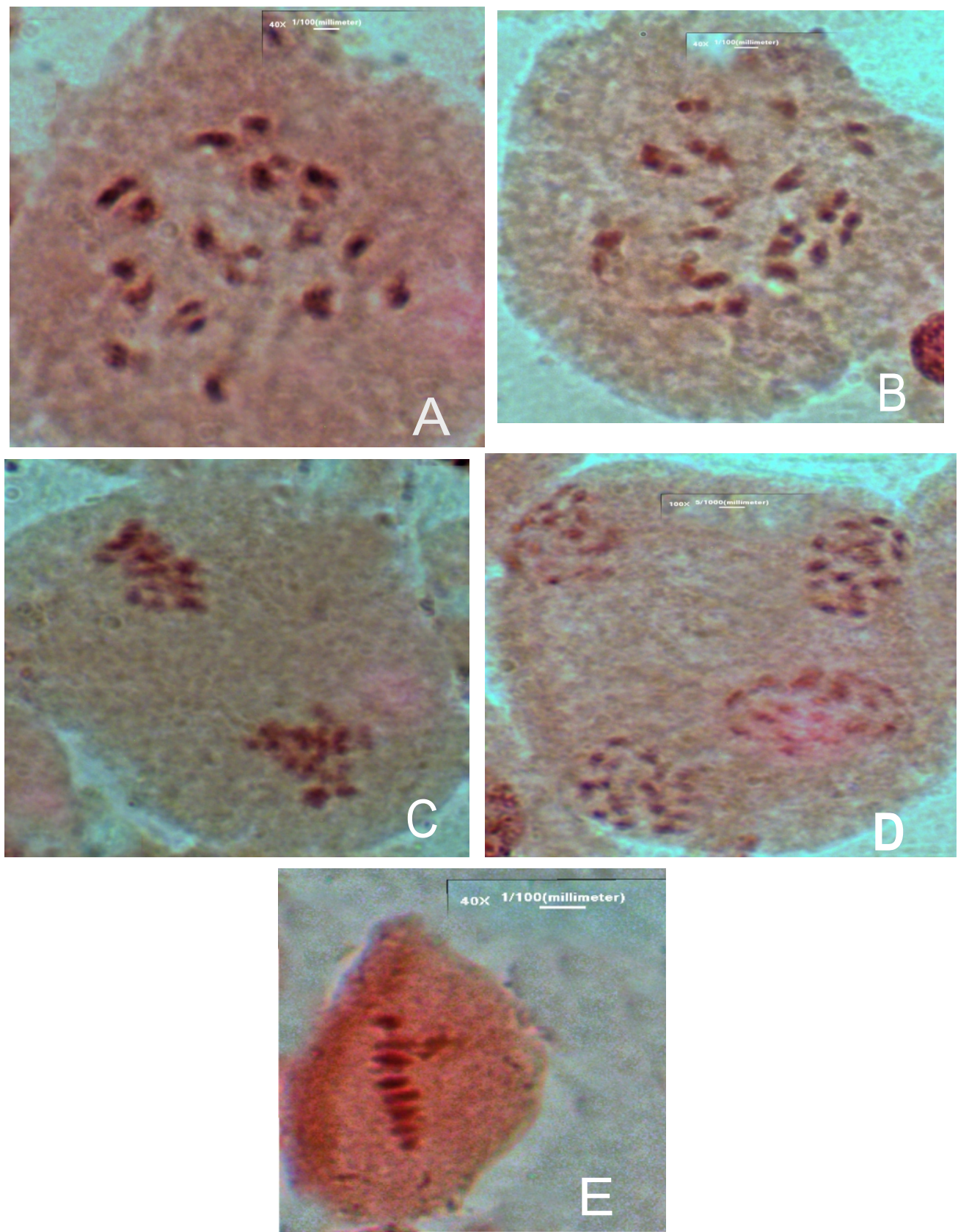

Plate 1: Chromosomal segregation for selected plant species from the study area, Eleweran, Ile-Ife, Osun State

Key A - Diakinesis in Talinum triangulare, $2 \mathrm{n}=36$

$\mathrm{B}-$ Diakinesis in Talinum triangulare, $2 \mathrm{n}=36$

$\mathrm{C}$ - Telophase I in Talinum triangulare, $2 \mathrm{n}=36$

$\mathrm{D}$ - Telophase II in Talinum triangulare, $2 \mathrm{n}=36$

$\mathrm{E}$ - Metaphase I in Paspalum conjugatum, 2n $=20$

Note regular pairing at diakinensis and lack of lagging at telophase 


\section{DISCUSSION}

The results of the cytological examination suggested that the plant species targeted did not show cytotoxic and genotoxic effects as a result of herbicide application. Herbicide application did not affect the meiotic process and pollen formation of the plants studied. Pollen data were consistent with the observation of regular meiosis. The major effect of herbicide application on the long-surviving plants studied was reduction in the above-ground biomass which manifested as reduction in tillers for grasses and branches for the forbs and weeds. Leaves in contact with herbicides appeared burnt or riddled with necrotic spots. These plants managed to recover their biomass, then flowered and set seed. Hence, somatic damage does not necessarily result in reproductive failure. This result was similar to that of the Faluyi and Nwokeocha (2001) particularly in respect of the somatic damage being transient and not having gross genotoxic effect on the plants. As the initial effect on the leaves of the sprouting cassava recovered in two months, the somatic damage to the plants in this study did not show in the new flushes suggesting that, in a whole-plant system, damages can be readily reversed because the entire homeostatic control system is operational.

The cytological events in the plants studied contradict the result of Haliem (1990), Topaktas and Rencuzogullari (1991), Pandey (2008) and Kumar and Jagannath (2015) on the cytotoxic effects of pesticides on plants where a variety of chromosomal abnormalities were reported at increasing concentration of pesticide application.

The results presented in this aspect of the study show that plants that are long-living as a result of the nature of their perennating mechanisms theoretically are able to survive herbicide application without manifesting cytotoxic and genotoxic effects. They, therefore, have a relative advantage of fitness (where fitness is defined sensu-stricto as ability to contribute propagules to the next generation) in terms of being able to contribute seeds to the seedbank from which seedlings may recruit in succeeding generations.

\section{REFERENCES}

Faluyi, J.O. and Nwokeocha, C.C. 2001. Cytogenetic monitoring of irradiation dosage regimes in four cassava (Manihot) varieties. Annals of Agricultural Sciences 2(1):64-73

Haliem, A.S. 1990. Cytological effects of the herbicide sencorer on mitosis of Alium cepa Egyptian Journal of Botany 33:93-104

Kumar, H. N.K. and. Jagannath, S. 2015. Cytological effects of herbicide butachlor 50 EC on somatic cells of Triticum aestivum L. Journal of Applied Biology and Biotechnology 3(02):30-34.

Lasebikan, A. B. and Olorode, O. 1972. Morphological variation and cytological abberations in the natural populations of Zonocerus variegatus L. (Orthoptera pyrgomorphidae) Bulletin of Entomological Society of Nigeria 3:127-133.

Njagi, C.D.E., Goplan, H.N.B. 1981. Mutagenecity testing of herbicides, fungicides and insecticides. I. Chromosome aberration in Vicia faba. Cytologia 46:169-172.

Olorode. O. and Barquar, S.R. 1976. The Hyparrhenia involucrata-H. Subplumosa (Gramineae) complex in Nigeria. Morpholological and cytological characterization. Botanical Journal of Linnean Society 72:212-222

Pandey, R.M. 2008. Cytotoxic effects of pesticides in somatic cells of Vicia faba L. Cytology and Genetics 42:373-377

Topaktas, M. and Rencuzogullari, A. 1991. Cytogenetic effects of herbicides gasegard and igran in barley. Cytologia 56:419-424.

Vencill, W.K., Nichols, R.L., Webster, T.M., Soteres, J.K., Mallory-Smith, C., Burgos, N.R., Johnson, W.G. and McClelland, M.R. 2012. Herbicide Resistance: Toward an Understanding of Resistance Development and the Impact of Herbicide-Resistant Crops. Weed Science 60: Special Issue: $2-30$ 